\begin{tabular}{|l|l|}
\hline Asian Journal of Pharmaceutical Research \\
and Development
\end{tabular}

Open $\odot$ Access

www.ajprd.com

Review Article

\title{
REDEFINING THE SCOPE OF AYURVEDA IN CARDIOLOGY
}

\section{Fasnath Arabi, 2Jithesh M*}

1PG Scholar, Department of Manovijnan, V.P.S.V Ayurveda College, Kottakkal, Kerala, India

$2^{*} \mathrm{HOD}$ and Associate Professor, Dept. of Kayachikitsa and Post Graduate Studies in Manovijnan, V.P.S.V

Ayurveda College, Kottakkal, Kerala, India

\begin{abstract}
Cardiovascular diseases (CVDs) have now become the leading cause of mortality or even morbidity in India. According to the World Health Organization, cardiovascular disease causes 12 million deaths in the world each year. Even with all the advancements in medicine, the management of CVD's are yet to be redefined. Ayurveda proposes a different understanding to etiopathogenesis of such conditions and subsequent healthcare, in the context of hrdroga. Latest researches in Ayurveda have given a new hope in CVD's, the curative as well as preventive aspects. With the emergence of increasing number of cardiac problems from the young age itself, it is the time to explore various options available in the alternative areas of medicine. Herbs and dietary supplements can have significant role in preventive cardiology as per published studies. Equivalent is the management of associative psychological contributors. In this article, research works of medicinal plants useful in cardiology are described with special emphasis on rasona, arjuna, guggulu, amalaki and gokshura. This work emphasises the scope of such practice so as to popularize the options available in Ayurvedic literature.
\end{abstract}

Key words: Hrdroga, CVD, Prevention strategy, hrcchula, rasayana

Article Info: Received:21 Sept 2018; Review Completed:30 Sept, 2018; Accepted: 10 Oct,2018; Available online:20 Oct,2018

Cite this article as:

Fasnath Arabi, Jithesh M, Redefining the Scope of Ayurveda in Cardiology, Asian Journal of Pharmaceutical research and Development. 2018; 6 (5): DOI: http://dx.doi.org/10.22270/ajprd.v6i5.431

*Address for Correspondence:

Jithesh M, HOD and Associate Professor, Dept. of Kayachikitsa and Post Graduate Studies in Manovijnan, V.P.S.V Ayurveda College, Kottakkal, Kerala, India

\section{INTRODUCTION}

$\mathrm{I}$ n the current scenario, cardiovascular disease (CVD) is considered as one of the major cause of morbidity and mortality. The Global burden of disease is estimated at about 272 death per lakh population and mortality rate is increased by $59 \%$ in India ${ }^{1}$. The current management modalities have their own limitations and the available drugs have considerable adverse effects on continuous use. Hence, it is the need of the hour to detect safe as well as effective treatment for CVD's and here Alternative treatments such as Ayurveda are having a major role to play. A detailed description about Hridroga with its aetiopathogenesis as well as management is available in Ayurvedic parlance. This includes not only diseases of the hridaya or the heart, but also several other associative conditions affecting the functions of the heart. Even the hridroga due to krimi have been narrated, even much before the streptococci was invented of affecting the heart valves. Along with the etiological factors, dietary, lack of

exercise as well as psychological factors are being said to involve. Hrdaya is one of the vital organ or maha marma explained responsible for the maintenance of life. It is the unique seat of Sadhaka Pitta, Avalambaka Kapha and Vyana Vayu, all together governs the functions of not only circulatory system but also emotional aspects and is explained as the seat of manas. The hrdaya is a pulsating organ $^{2}$ placed in the thoracic cavity, left to it are pleeha and phuppusa and right to it are Yakrta and Kloma ${ }^{3}$. Embryologically, it is originated from maternal characters and rakta and Kapha are the main contributors to its initial formation ${ }^{4}$. Symptoms of heart disease are also observed in the disorders of other systems such as gastrointestinal, respiratory etc. and are an area of differential diagnosis in many. Ayurveda explains diverse as well as novel views regarding the etiopathogenesis, manifestation as well as management in hridroga. Conditions such as angina is explained as hrcchula ${ }^{5}$ by Susruta, characterized by chest pain as well as dyspnoea, happening due to obstruction of Vatha by the vitiated rasa dhatu. The management recommended for hrcchula and hrdroga are similar and a preventive aspect is stressed with the importance of the use of various rasayanas. These are also aimed at the prevention of possible relapse in Ischemic Heart Diseases. 


\section{Etiological factors of hridroga}

Ayurveda emphasizes multiple causative factors for hrdroga as over exertion, excessive exercise, and excess administration of sodhana therapies, vamana, virechana, vasthi etc. General diseases causing sosha, certain psychological factors like excessive worry, fear, stress, mental trauma, physical trauma directly affecting heart all of which may lead to hrdroga. ${ }^{6}$ In a similar manner, suppression of natural urges (vegadharana) such as that of thirst, tears, srama swasa, adhovata and cough also contributes to hrdroga ${ }^{7}$. The suppression of natural urges cause distorted functioning of Vatha which may ultimately and insidiously lead to hridroga. Ayurveda explains the metabolic syndrome in the context of sthoulya and prameha which is contributing to problems of hridaya, nowadays. These factors, when studied in detail in the light of modern physiology points to the fact of several other clinical conditions resulting ultimately in hridroga.

Researchers have identified several reasons behind the impact of psychological factors affecting heart as well as its function. The stress alters function such as the rise in adrenaline release, raising blood pressure and heart rate, which can injure the lining of the arteries or there is increased need for oxygen, which may cause angina in cardiac compromised subjects.

\section{Pathophysiology}

Basically two types of mechanism of pathogenesis is explained for hrdroga. One is 'functional derangement' due to improper nidana sevana and deranged agni. The status of agni is very much significant here as it results in Saama rasa dhatu production. This vitiated saamarasa when combine with the associative doshas such as Pitta and Kapha causes Srotorodha. Based on the associative dosha, the manifestation and symptomatology varies of the ischemia or chest pain. When saamarasa mixes with prana vayu, it leads to acute onset of pain in pericardial region (angina) and breathing difficulty, the acute manifestation. Second type describes any 'organic change' in the cardiac structure with the alteration of the structure. Conditions such as pericarditis, cardiomyopathy, mediastinal swelling etc. are such conditions of serious nature. Similar is the case of krimija hridroga as explained in classics. Even hridaya is being explained as a site of vidradhi as well as gulma to manifest in subjects. Here the management depends mainly on the underlying cause.

\section{Principles of management of hridroga}

Ayurvedic system of medicine is promising as well as generating hope for managing as well as preventing the evolving cardiac diseases. Ayurveda exerts special emphasis on both preventive and curative aspects in all conditions including hrdroga. Here while managing heart disease, the factors under consideration are the causative factors such as Ama, agni, status of Rasavaha srotus, ojus and even the psychological status of the individual. Anulomana of Vatha is very much significant as Vatha is the dominant dosha in the manifestation. Sodhana if possible after considering the bala is the best available option followed by rasayana. Conditional samana therapy is advisable in those not fit for sodhana. The drugs acting on hrdaya are categorized under deepana, pacana, vatanulomana, hrdya, balya, and rasayana. Management of the psychological aspects is so significant with the other therapies.

\section{Prevention of cardiac diseases- Ayurvedic wisdom}

Intake of wholesome and unwholesome diet is responsible for prevention and manifestation of various clinical conditions. One should have to follow a daily diet with the rules for food intake by considering ahaara vidhi mentioned in classics, which is the cardinal aspect of preventive medicine. The preventive approach to cardiology can be categorized under - Population strategy, Primordial, Primary \& Secondary prevention

Population strategy: Preventive approach is directed towards whole population not merely in individuals. Ayurveda principles such as daily routines which includes regular physical exercise, proper control of sareera as well as manasa vegas, sadvritta ( following the right conducts of life) and dietary rules can be propagated to society through public awareness at all levels commencing from the primary education itself.

Primordial prevention: Prevention starts with correction of the basic lifestyle. Ayurveda has enough choices to regain the true rhythm of nature by synchronizing it with that of the nature. Proper administration of Dinacharya, which includes regular exercise, bath, prayer, meditation and wholesome diet, Ritu charya ie the seasonal purification and Sadvritta as well as Achaara rasayana which includes personality development and mental health care aids to this primordial prevention level by prevention of the possible risk factors.

Primary Prevention: Incorporating dietary changes like reduced intake of salt, increased consumption of vegetables, fruits, pulses and cereals and lifestyle modification like daily exercise, control hypertension, avoidance of alcohol and smoking etc. lies at the level of primary prevention by delaying or preventing the onset of disease. This is very much significant in those with family history of CVD.

Secondary Prevention: The aim of secondary prevention is to prevent the recurrence and progression of the disease. Ayurveda explains different herbs which helps the better functioning of hrdaya at the optimum level. Ayurveda suggests ahara, vihara including psychological factors and continous use of appropriate medicines. In classical texts, several ganas such as hrdya dashemaani by Charaka, Parushakadi gana by Susruta and Vidaryadi gana by Vagbhata are aimed at better management of the conditions of hrdaya.

\section{Medicinal plants and their role}

Ayurveda offers diverse herbal medicines which can play a role in managing and preventing several aspects of CVD. 
Table no. 1: Cardio protective single drugs in Ayurveda

\begin{tabular}{llll}
\hline $\begin{array}{l}\text { Agnideepana \& } \\
\text { Vata anulomana }\end{array}$ & Lekhaneeya & Hrdya & Other beneficial drugs \\
\hline $\begin{array}{l}\text { Ajamoda, hingu, pippali, } \\
\text { sunti etc }\end{array}$ & $\begin{array}{l}\text { Vaca, haridra, guggulu, } \\
\text { daruharidra etc }\end{array}$ & $\begin{array}{l}\text { Amra, amrataka, lakucha } \\
\text { kuvala, matulunga } \\
\text { karamardaka etc. }\end{array}$ & $\begin{array}{l}\text { Gokshura, pushkaramoola, } \\
\text { arjuna, silajatu, punarnava, } \\
\text { brahmi, rasona, vanapalandu }\end{array}$ \\
\hline
\end{tabular}

Table no. 2: Examples of formulations with action on Hridaya

\begin{tabular}{|c|c|c|c|c|c|}
\hline Ghrtm & Kwatam & Gutika & Coornam & Rasayana & Arishtam \\
\hline $\begin{array}{l}\text { Pipplyadi } \\
\text { Ghrita, } \\
\text { sunti ghrtm, } \\
\text { arjuna } \\
\text { ghrtm }\end{array}$ & $\begin{array}{l}\text { Pathyadi Kwatha, } \\
\text { dasamoola ks, } \\
\text { Rasonadi kwatha } \\
\text { Vidaryadi kwatha }\end{array}$ & $\begin{array}{l}\text { Shilajitwadi vati, } \\
\text { Chandraprabha vati, } \\
\text { Prabhakara Vati } \\
\text { Hridayarnava rasa }\end{array}$ & $\begin{array}{l}\text { Arjuna twak churna, } \\
\text { Pippalyadi churna } \\
\text { haritakyadi churna, } \\
\text { Hinguvachadi churna } \\
\text { Dwiruttara churna }\end{array}$ & $\begin{array}{l}\text { Amalaki } \\
\text { rasayana } \\
\text { Agasthya } \\
\text { rasayana, } \\
\text { Bhallataka } \\
\text { Pippali } \\
\text { rasayana }\end{array}$ & $\begin{array}{l}\text { Parthadyarishtam } \\
\text { Arjunarishtam }\end{array}$ \\
\hline
\end{tabular}

\section{RESULTS OF PUBLISHED RESEARCH WORKS}

Effect of certain selected medicinal plants on hrdroga is described below on the basis of reported studies:

\section{Rasona - Allium sativum}

Effectiveness of garlic in CVD was more encouraging in experimental studies as well as several clinical trials. Allicin, the principal bioactive compound is responsible for the beneficial effect on cardiovascular system which includes reduction in atherosclerosis, antihyperlipidemic effect, inhibition of platelet aggregation, blood pressure lowering effect, significant anti arrhythmic effect and prevents oxidative stress and associated ultra structural changes induced by myocardial ischemic reperfusion injury. A double-blind cross-over study was conducted to assess the effect of with $7.2 \mathrm{~g}$ of aged garlic extract compared with placebo on moderately hypercholesterolemia men. This study reported that reduction of $6.1 \%$ in total serum cholesterol levels and $4.6 \%$ in LDL cholesterol levels with garlic compared with placebo $^{10}$.

\section{Gokshura - Tribulus terrestris}

The biological properties of Tribulus include diuretic, increased release of nitric oxide from endothelium and nerve endings; it relaxes smooth muscles and increases angiotensin converting enzyme (ACE) inhibition and hence reduces the hypertension. Saponin present in it dilates the coronary artery and improving coronary circulation. An experimental study conducted in rats proved that improvement in Cardiac Function and attenuates myocardial Infarction 10. Gokshura is one of main ingredient of Hrdya coorna (combination of gokshura, arjuna and sthira) which is commonly practiced in our cardiology OPD in ischaemic heart disease.

\section{Arjuna - Terminalia arjuna}

Arjuna improves function of cardiac muscle and subsequently improves pumping activity of the heart. In hypertensive heart diseases, decoction made of bark powder was found more effective as compared to congestive heart disease. Studies proved the benefits of Terminalia arjuna in the treatment of coronary artery diseases, heart failure, and hypercholesterolemia and the cardioprotective activity was due to its free radical scavenging activity as reported. Experimental study proved that Terminalia arjuna have cardioprotective effect against the damage caused by caffeine administration. Animal studies suggest that Terminalia can reduce high blood lipids levels ${ }^{10}$.

\section{Amalaki -Embilica officinalis}

In Ayurveda, amalaki, one of the effective rasayanas available, is reported to be beneficial in the treatment of respiratory, cardiovascular, rheumatic diseases as well as in diabetes. Various experimental studies suggested the antioxidant and hypolipidemic effects of Amalaki. Clinical Studies proved that amalaki produced significant hypolipidemic effect along with a reduction in blood pressure. It also offers significant protection against atherosclerosis and coronary artery disease. The drug contains high amounts of vitamin $\mathrm{C}$ in the natural form as well as cytokine-like substances identified as zeatin, Zriboside, Z-nucleotide, flavonoids pectin, and $30 \%$ tannins. Studies proved that flavanoid and pectin decrease serum cholesterol levels in human beings ${ }^{11}$.

\section{Guggulu-Commiphora mukul}

Guggulu has better hypolipidaemic effect because of presence of resin in it and it has Kapha as well as Medohara effect as per Ayurveda texts. Various studies have indicated to the good effect of Sudha Guggulu and other Ayurvedic formulations like Amritadi Yoga, Navaka Guggulu, pushkara guggulu, vyoshadi guggulu on hyperlipidemia. Pushkara guggulu showed significant reduction in serum lipid levels and pericardial pain and dyspnoea on effort. Vyoshadi guggulu along with Hareetaki coorna showed significant result in Obesity and reduce serum cholesterol level. The experimental study done on albino rats reported that Suddha Guggulu has cardioprotective activity as it has increased the HDL Level and this drug also reduced the serum triglycerides to 
significant level and thus provided antiglycaemic activity as well ${ }^{12}$.

\section{Areas for Future research}

There is a immense need of wide research to find out the actual relationship between hrdroga and contemporary cardiac diseases, to prove the efficacy of many herbs and formulations described in classics for hrdroga, to find out the constituents responsible for specific actions and to understand dose, potential risks and benefits in various cardiac problems, along with their possible toxicological studies. The detailed investigation of the plants and their constituents will lead to the development of new formulations for the management of heart diseases.

\section{CONCLUSION}

Cardiovascular diseases are discussed and addressed under the context of Hridroga in Ayurveda. Several herbs

\section{REFERENCES}

1. Prabhakaran D, Jeemon P, Roy; A Cardiovascular Diseases in India: Current Epidemiology and Future Directions. 2016 Apr 19;133(16):1605-20

2. Sharma P. Dalhana commentary of Sushruta Samhita, sareera sthana, chapter 4 verse no. 30 Varanasi: Chaukhambha Visvabharti Publications; 2005

3. Acharya YT. Ayurveda Deepika Commentary of Chakrapanidatta on CharakaSamhitha, sareera sthana, chapter. 4 verse 15, Reprint edition: Varanasi: Chaukamba Orientalia, 2015; p.450-9

4. Sharma P. Dalhana commentary of Sushruta Samhita, sareera sthana, chapter 3 verse no. 31 Varanasi: Chaukhambha Visvabharti Publications; 2005

5. Sharma P. Dalhana commentary of Sushruta Samhita, uthara tantra, chapter45 verse no. 12 Varanasi: Chaukhambha Visvabharti Publications; 2005

6. Yadavji Trikamji Acharya, Agniveshakrita Charaka Samhita Chakrapani Commentary, Chikitsasthan26/77,Varanasi, Chaukhambha Sanskrita Sansthan, 2009. and supplements act as adjuncts in the prevention and treatment of cardiovascular disease. Herbs such as Rasona, Gokshura, Arjuna, Amalaki, Guggulu and their formulations are safe and effective in treating cardiac diseases. Such drugs have Anti hyperlipidemic property, inhibits platelet aggregation, lowers blood pressure, antiatherogenic and cardioprotective properties. One should follow a balanced diet, exercise and avoid habits such as smoking, alcohol, manage stress, so that we can prevent cardiac diseases.

The eternity of Ayurveda is in the sense of the great affection that it has in its approach to the diseases, people and life as a whole. The scientific understanding of various clinical aspects if applied in the management of problems such as CVD's may create wonders in cardiological issues in the curative as well as preventive levels. We have to concentrate a lot, in possible researches and their outcomes for further conclusions.

7. Hemadri; Sarvanga Sundhara Commentary of Arunadatta on Ashtanga hrdaya; sootra sthana, chapter 4, verse no. 3- 20; Reprint Varanasi (India): Chaukambha Orientalia: 2005

8. Pratibha mamgain and R.h. singh; a critical study of the concept of ischemic heart disease in Ayurveda; Ancient Science of Life, Vol No. XIII Nos. 1 \& 2, July-October 1993, Pages $102-110$

9. Dr.P.Sudhakar Reddy, Dr.Beena MD; Conceptual review on Prevention of Cardiovascular diseases in Ayurveda w.s.r to Hridya; International journal of Ayurveda \& herbal medicine 7(1) Jan.-Feb..2017(2429-2435)

10. Dr Subrat Bhutia; role of certain medicinal plants on cardiovascular disorders; Indian Journal of Medical Research and Pharmaceutical Sciences February 2016; 3(2)

11. Biswas Gop; A comparative clinical study of hypolipidemic efficacy of Amla (Emblica officinalis) with 3-hydroxy-3methylglutaryl-coenzyme-A reductase inhibitor simvastatin; Indian J Pharmacol. 2012 Mar-Apr; 44(2): 238-242.

12. Sapra umesh kumar;Antihyperlipidemic effect of Panchatikta ghana and Suddha guggulu- an experimental study , Journal of Ayurveda and Holistic Medicine April, 2013 Vol 1 Issue 1 